\title{
STATISTICAL STUDY OF INCOME AND EXPENDITURE HOUSEHOLDS IN THE REPUBLIC OF UZBEKISTAN
}

\author{
Samandar Kosimov ${ }^{1}$, Khaidar Kuvnokov Ph.D. ${ }^{2}$ \\ ${ }^{1}$ Basic Doctoral Student of the Institute of Advanced Training and Statistical Research, \\ Republic of Uzbekistan \\ ${ }^{2}$ Associate Professor, Tashkent State Agrarian University, Republic of Uzbekistan
}

Article DOI: https://doi.org/10.36713/epra8539

DOI No: 10.36713/epra8539

\begin{abstract}
The purpose of the study is to clarify the theoretical approaches associated with the formation and forecasting of household cash income, and to develop, on this basis, methodological recommendations for forecasting them in the system of regional accounts. To achieve this goal, the following tasks have been set: research and clarify theoretical and methodological approaches to the formation and forecasting of household income at the regional level; show the evolution of the economic essence of household income in the theoretical views of foreign and Uzbek researchers, systematize the basic principles of the formation of household income, necessitating the need to clarify the definition of household income, highlight the features of the formation of shadow income and informal household income in order to assess the impact of these processes on the formation of cash household income, to formulate the main directions of improving the study and forecasting of household cash income at the regional level, to carry out predictive experimental calculations of household cash income of the constituent entity of the Republic of Uzbekistan.
\end{abstract}

KEYWORDS: Republic of Uzbekistan, statistics, income, expenditure, households, system of national accounts

\section{INTRODUCTION}

The transition to a market economy has radically changed the conditions for the formation of the population's income. On the one hand, there appeared opportunities for the manifestation of entrepreneurial abilities, a fuller realization of the knowledge and skills of workers, the intensification of labor activity, on the other hand, the general economic conditions for the formation of incomes of Uzbek citizens worsened, their social security decreased, and the economic and social differentiation of incomes sharply increased. Of "shock" reforms, more than half of the country's population fell below the poverty line in terms of real incomes, the structure of the population's monetary income was deformed - the component of official wages (labor income) was declining and the share of "hidden" (shadow) incomes increased [1].

At present, the problematic issues of analyzing and forecasting the population's monetary income, determining their place in the economic system of Uzbekistan remain relevant, their importance from a theoretical and practical point of view is increasing. In economic theory, the problems of income formation are among the traditional, fundamental today income, as a form of reflection of economic relations in society, is undergoing significant changes, especially in the economic aspect. Ending the period of economic transformation, Uzbekistan is recognized as a market economy, but the elements of the new economy [2], there are parallel with the continuing administrative and planning s mechanisms of formation of incomes of the population, none of them does not work in full as income only a small part of society formed in accordance with the market principles. Basically, there is a decrease in the share of wages in the structure of income of the population and an increase in the level of unofficial "shadow" income [3].

A holistic concept, implemented on the basis of new methodological and informational approaches of the system of national accounts, taking into account the experience of market management, which determines the economic essence of household income, the mechanism of their formation and 
methods of forecasting, should become an effective instrument of regional policy [4].

\section{LITERATURE REVIEW}

The degree of scientific elaboration of the problem does not reflect the theoretical and methodological possibilities of modern research on the determination of household cash income at the regional level. The process of the formation of the population's income, the reasons and factors of income differentiation, the problems of measuring the well-being, the level and quality of life of the population, and other fundamental problems of the theory of income have become quite widespread among foreign researchers. It is possible to highlight the fundamental works of such scientists as Keynes JM, Malthus T, Marx K., Marshall A., Mill D.S., Petty U., Pigou A., Ricardo D, Say J.B., Smith A., Friedman M. and others.

The radical market transformations taking place in Uzbekistan have changed the essential features of the inhabitants, from the statistical category "population" they have become the main institutional sector of the economy - "household". other agents. Therefore, the problem of studying the formation of household cash income requires a systematic approach, which is especially important for mitigating the social consequences of economic reforms.

Today, the main methodological provisions have been formed in the field of analysis and forecasting of household cash income in the system of national accounts (SNA), that is, at the macro level [5].

The theoretical, methodological and applied significance of the problems of the formation and forecasting of household cash income in the system of regional accounts of the subjects of the Republic of Uzbekistan, as well as the relevance and degree of its elaboration, determined the goal, objectives, directions and methods of research [5].

\section{METHODOLOGY}

The theoretical and methodological basis of the study was the works of domestic and foreign experts on market economics, statistical analysis and modeling of complex socio-economic phenomena and processes. Methods of structural and analytical grouping, multidimensional methods of dimensionality reduction and classification, econometric methods, as well as tabular and graphical methods for visualizing research results were used for statistical research.

\section{FINDINGS AND DISCUSSIONS}

As a system of scientific views, the theory of income was formed in the second half of the 19th century and the question of the origin of wealth, its objective nature and causes (the theory of income generation), its fair distribution among members of society (the theory of income distribution) is still relevant. », Based on the processes taking place in the economic, social and political systems in a particular historical period of time. Having studied the history of the issue, having analyzed from a theoretical point of view the essence of the population's income, having examined the palette of modern views on the problem of the formation of household income in the system of national accounts, the following principles for determining household income were clarified and formulated [7].

1) Household income is formed as a result of economic production, in which the costs of one or more factors of production belonging to the household are carried out

2) Income is the portion of gross value added that goes to households.

3) It is necessary to clearly separate the concepts of "income," cash receipts", "inkind" and "property" for households.

4) Not all money received is household income.

5) Proceeds from the sale of household property and assumed financial obligations cannot be a source of income.

6) An increase in the value of property as a result of random causes (inflation, external and unforeseen circumstances, etc.) is not income.

The author has preserved all the fundamental principles for determining incomes, developed by the classics of political economy, with the clarification of their theoretical conclusions of modern scientists. At the same time, the formative role of economic activity in the process of income generation is highlighted and the need to differentiate income flows of the population and other cash and in-kind receipts of households is added.

The formation of household income is determined by the use of labor of household members by other institutional units (wages) and the use of property (income from property), as well as their labor in entrepreneurial activities (mixed income).

Household cash income is the amount of cash flowing into the disposal of households in the economy as a result of the primary distribution of gross value added, wages, mixed income, and property income. Compensation of employees according to the SNA methodology - this is compensation in cash or in kind for labor expended, and must be paid by the employer to the 
employee in the form of wage payment and social security contributions [8].

Mixed income - income obtained in the course of economic activity by unincorporated enterprises belonging to households, which contains elements of wages, business income and income from property used in this production.

The income from the property allocated dividends from the investment of working time, which includes income from the funded part of the pension, insurance reimbursement by the voluntary insurance and cash payments of membership in nonprofit organizations (trade unions, community organizations, and others. These revenues are identified and grouped according to the following criteria (1) personification, (2) the ability to manage their investments, (3) dividends depend on the volume of investments made, (4) as a rule, these investments are made by people of working age [9].

In-kind income of households - consists of external incomes that come from other sectors of the economy, and internal incomes that are formed within the household itself. The study and measurement of natural internal income is necessary, since the growth of household "self-service", the rejection of the active exchange of resources and the naturalization of domestic labor, characterize the deterioration of the material situation and the lack of income. In this sense, the relationship between the household and the service sector is both an indicator of household welfare and an indicator of the level of economic development of the country [10].

Household income is the monetary and in-kind income received by this sector of the economy as a result of the primary distribution of value added, wages, mixed income, income from property, i.e. income received by households as participants in the production process (market or personal) or owners of factors of production. which are used for production purposes.

The author's definition of household income does not contradict the definition of primary household income in the SNA methodology (as factor income obtained directly from production activities), but it has a wider range of components of natural income.
The financial resources of the household - is the collection of all post singing at the disposal of the household money, those cash revenues and cash flows redistributed. Therefore, this is the maximum amount of money that households, after paying mandatory taxes and payments, can afford to spend on final consumption and saving in the reporting period without reducing household assets or increasing financial liabilities. This indicator is comparable by definition to household disposable income in the SNA methodology.

Income of households - it is money and natural resources post upayuschie available to households at the stage of redistribution of the gross value added. They are shaped in the form of redistributed remittances and social transfers in kind form. These funds are not income, because redistributive rather than production processes underlie their formation. However, they affect the consumer behavior of households, forming the total resources of the household, which is understood as the aggregate of material goods and services that households can spend on final consumption and saving in the reporting period without reducing cash, liquidating assets or increasing liabilities. According to this definition, the total resources of a household are theoretically consistent with the concept of adjusted disposable income as defined in the SNA methodology. However, our interpretation is broader due to the inclusion in the boundaries of production activities of all types of activities, including household activities for personal consumption. This indicator also corresponds to the indicator of total income, which is the statistical equivalent of the amount of subsistence that the population receives to meet its needs, regardless of the source of income. The total resources of households characterize the current income during a certain period of the study. However, the potential of a household is determined not only by current receipts, but also by the amount of accumulated property belonging to the household. The formation of the resource potential of the household is shown in Figure 1. 


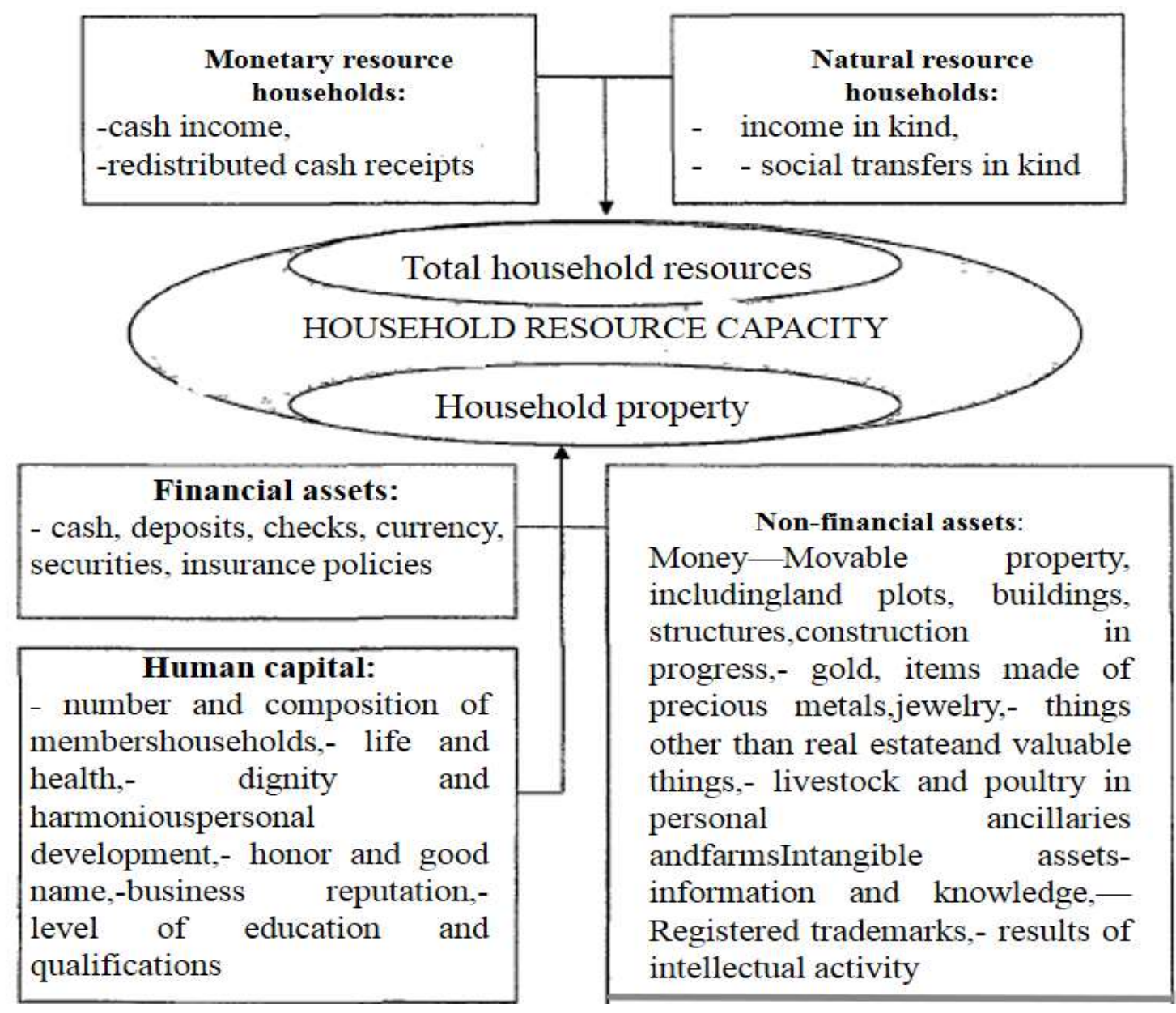

Figure 1. Formation of the resource potential of the household

Household property is formed at the expense of (1) financial assets, (2) non-financial assets, which are subdivided into tangible and intangible, and (3) human capital.

The resource potential of a household covers all available means, opportunities and sources that a household can use in economic (entrepreneurial) activities for the production of market goods and services, spend on final personal consumption or savings. It is almost impossible to quantify all components of the resource potential of a household, since there is no methodological and information base for some indicators:

- it increasingly regards estimates Natural 's income and other indicators have a subjective characterdefinition of human capital. Therefore, the most accessible and reliable for quantitative and qualitative analysis and forecasting are resources directly represented in monetary form or having a monetary value equivalent to the monetary resource of a household, financial and material assets.

To characterize and assess the liquidity of households, as the ability of a household to fully meet all of its financial and other obligations, the following indicators have been introduced.

1) Monetary aggregate of household's $\mathrm{MdO}$ the aggregate of all cash in circulation in a household, which includes the monetary resource and financial assets represented by cash.

2) The monetary aggregate of households $M \partial 1$ includes the monetary aggregate of households МДО and financial assets, in the form of deposits, checks, foreign currency.

3) Household monetary

aggregate $M d 2$ includes household monetary

aggregate Md1 and financial assets in the form of securities and insurance policies.

Household monetary aggregates MDO, MD1 and MD2 are characteristics of household money supply (DMd)

In order monetary and financial analysis sector domestic households, assessing the level of their welfare proposed indicators in conjunction with the performance of financial obligations households can act as characteristics excess liquidity households (in 
aggregate $\mathrm{MgO}$ ), high household liquidity (by unit MD1) Current households (by aggregate Md2). The monetary base of households $(D B D)$ characterizes the monetary - credit policy pursued by the household. Therefore, this concept is broader than the concept of the money supply of households, since it is measured not only by the amount of cash and financial assets at the disposal of households [11], but also by the amount of material assets of households in the form of gold, precious metals, jewelry and antiques. Products [12].

\section{RECOMMENDATIONS}

Household spending in Uzbekistan in 2019 amounted to $\$ 31.5$ billion, ranked 86th in the world and was at the level of Congo household expenditure (\$33.5 billion), Lithuanian household expenditure (\$ 33.1 billion), Jordanian household expenditure (\$ 32.8 billion). USD), household expenditures in Oman (USD 31.0 billion), Sudanese household expenditures (USD 31.0 billion). The share of household expenditures in Uzbekistan in the world amounted to $0.064 \%$ [13].

Household spending per capita in Uzbekistan in 2019 was \$ 955.8, ranked 172nd in the world and was at the level of household expenditure per capita in Lesotho (\$ 979.4), household expenditure per capita in Pakistan (\$ 975.0), household expenditure per capita in Senegal (\$ 969.2) [14], per capita household expenditure in Mauritania (\$ 951.5), per capita household expenditure in Yemen (\$ 897.5). Household expenditures per capita in Uzbekistan were less than per capita household expenditures in the world $(\$ 6,415.4)$ by $\$ 5,459.6$.
Comparison of household expenditures in Uzbekistan and neighbors in 2019. Household expenditures in Uzbekistan were 4.5 times higher than that of Kyrgyz households $\left(\begin{array}{ll}\$ & 6.9\end{array}\right.$ billion), Tajikistan's household expenditures (\$ 6.3 billion) were 5.0 times higher, and Turkmenistan's household expenditures ( $\$ 5.3$ billion) were 6.0 times, but were less than household expenditures in Kazakhstan (\$ 94.4 billion) by $66.6 \%$ [15]. Household expenditures per capita in Uzbekistan were more than per capita expenditures of households in Turkmenistan $(\$ 884.8)$ by $8 \%$, household expenditures per capita in Tajikistan $(\$$ 679.0 ) by $40.8 \%$, but were less than household expenditures per capita population in Kazakhstan (5,091.1 dollars) by $81.2 \%$, household expenditures per capita in Kyrgyzstan (1,081.4 dollars) by $11.6 \%$.

Comparison of household expenditures in Uzbekistan and leaders in 2019. Household expenditures in Uzbekistan were less than US household expenditures ( $\$ 14,544.6$ billion) by $99.8 \%$, Chinese household expenditures $(\$ 5,585.9$ billion) by $99.4 \%$, Japanese household expenditures ( $\$ \quad 2,805.1 \quad$ billion) by 98.9 $\%$, household expenditures in Germany $(\$ 2,022.7$ billion) by $98.4 \%$, UK household expenditures ( $\$$ $1,808.5$ billion ) by $98.3 \%$. Household expenditures per capita in Uzbekistan were less than household expenditures per capita in the United States (\$ 44,200.0) by $97.8 \%$, household expenditures per capita in the United Kingdom (\$26,781.3) by $96.4 \%$, household expenditures per capita in Germany (\$ $24,219.8)$ by $96.1 \%$, per capita household expenditures in Japan $(\$ 22,111.4)$ by $95.7 \%$, per capita household expenditures in China $(\$ 3,896.1)$ by $75.5 \%$.

Household expenditures in Uzbekistan, 1990-2019

\begin{tabular}{|c|c|c|c|c|c|c|c|c|}
\hline \multirow{2}{*}{ year } & $\begin{array}{c}\text { household } \\
\text { expenditures, } \\
\text { billions of }\end{array}$ & $\begin{array}{l}\text { household } \\
\text { expenditures } \\
\text { per capita, }\end{array}$ & $\begin{array}{l}\text { Household } \\
\text { expenses , } \\
\text { USD }\end{array}$ & $\begin{array}{c}\text { growth of } \\
\text { household } \\
\text { expenditures, \% }\end{array}$ & \multirow{2}{*}{$\begin{array}{c}\text { share of } \\
\text { household } \\
\text { expenditures } \\
\text { in GDP,\% }\end{array}$} & \multicolumn{3}{|c|}{$\begin{array}{c}\text { share of } \\
\text { Uzbekistan, \% }\end{array}$} \\
\hline & \multicolumn{2}{|c|}{ current prices } & \multicolumn{2}{|c|}{ constant prices 1990} & & $\begin{array}{l}\text { in the } \\
\text { world }\end{array}$ & $\begin{array}{c}\text { in } \\
\text { Asia }\end{array}$ & $\begin{array}{c}\text { in } \\
\text { Central } \\
\text { Asia }\end{array}$ \\
\hline 1990 & 12.6 & 618.3 & 12.6 & & 71.4 & 0.094 & 0.42 & 33.2 \\
\hline 1991 & 11.9 & 569.3 & 11.5 & -8.8 & 65.4 & 0.084 & 0.37 & 33.4 \\
\hline 1992 & 8.7 & 406.7 & 8.2 & -28.5 & 52.7 & 0.057 & 0.24 & 30.1 \\
\hline 1993 & 11.1 & 506.1 & 10.2 & 24.3 & 67.0 & 0.071 & 0.27 & 35.0 \\
\hline 1994 & 11.9 & 535.0 & 10.8 & 5.7 & 74.7 & 0.072 & 0.27 & 37.1 \\
\hline 1995 & 9.5 & 417.8 & 8.4 & -22.0 & 58.8 & 0.052 & 0.19 & 34.7 \\
\hline 1996 & 10.8 & 462.8 & 9.2 & 8.5 & 64.2 & 0.057 & 0.22 & 38.0 \\
\hline 1997 & 13.2 & 557.8 & 8.9 & -3.0 & 70.7 & 0.070 & 0.28 & 40.5 \\
\hline 1998 & 12.5 & 518.9 & 8.9 & 0.46 & 69.3 & 0.066 & 0.29 & 37.3 \\
\hline 1999 & 14.8 & 606.6 & 9.4 & 5.6 & 72.2 & 0.076 & 0.31 & 46.5 \\
\hline
\end{tabular}




\begin{tabular}{|l|c|c|c|c|c|c|c|c|}
\hline 2000 & 11.9 & 480.4 & 9.5 & 0.87 & 72.0 & 0.059 & 0.23 & 44.6 \\
\hline 2001 & 7.9 & 316.1 & 10.2 & 7.6 & 71.7 & 0.039 & 0.16 & 30.2 \\
\hline 2002 & 8.2 & 323.3 & 10.6 & 3.4 & 70.1 & 0.039 & 0.16 & 29.7 \\
\hline 2003 & 7.7 & 299.5 & 10.6 & 0.079 & 64.0 & 0.033 & 0.14 & 22.9 \\
\hline 2004 & 8.5 & 324.4 & 11.4 & 7.5 & 59.0 & 0.033 & 0.14 & 20.0 \\
\hline 2005 & 9.3 & 351.1 & 11.9 & 4.4 & 54.3 & 0.033 & 0.14 & 19.2 \\
\hline 2006 & 11.6 & 431.6 & 13.0 & 9.7 & 56.1 & 0.039 & 0.17 & 19.7 \\
\hline 2007 & 14.8 & 543.8 & 14.0 & 7.3 & 55.8 & 0.044 & 0.19 & 19.7 \\
\hline 2008 & 19.4 & 702.9 & 14.1 & 0.76 & 55.2 & 0.053 & 0.22 & 20.2 \\
\hline 2009 & 22.8 & 812.6 & 14.7 & 4.7 & 56.8 & 0.065 & 0.25 & 25.8 \\
\hline 2010 & 26.8 & 938.2 & 14.6 & -1.0 & 57.0 & 0.071 & 0.26 & 25.7 \\
\hline 2011 & 31.8 & $1,098.0$ & 16.5 & 13.4 & 56.0 & 0.076 & 0.27 & 25.1 \\
\hline 2012 & 36.9 & 1252.3 & 18.3 & 10.7 & 57.6 & 0.087 & 0.30 & 24.6 \\
\hline 2013 & 41.3 & $1,381.3$ & 20.2 & 10.1 & 59.9 & 0.094 & 0.33 & 23.1 \\
\hline 2014 & 46.1 & 1513.3 & 22.3 & 10.7 & 60.1 & 0.10 & 0.36 & 26.4 \\
\hline 2015 & 50.2 & 1624.1 & 24.9 & 11.8 & 61.4 & 0.12 & 0.39 & 30.3 \\
\hline 2016 & 51.5 & 1638.1 & 27.3 & 9.4 & 63.0 & 0.12 & 0.38 & 36.4 \\
\hline 2017 & 35.4 & 1107.9 & 28.3 & 3.9 & 59.9 & 0.077 & 0.25 & 25.4 \\
\hline 2018 & 28.2 & 868.3 & 30.0 & 5.9 & 55.9 & 0.058 & 0.19 & 20.1 \\
\hline 2019 & 31.5 & 955.8 & 32.0 & 6.7 & 54.4 & 0.064 & 0.20 & 21.8 \\
\hline
\end{tabular}

Household spending potential in Uzbekistan in 2019. With per capita household expenditures at the same level as household expenditures per capita in the United States $(\$ 44,200.0)$, household expenditures in Uzbekistan would be $\$ 1,457.9$ billion, which is 46.2 times higher than the actual level. With household expenditures per capita at the same level as household expenditures per capita in the world $(\$ 6,415.4)$, household expenditures in Uzbekistan would be \$211.6 billion, which is 6.7 times higher than the actual level. With household spending per capita at the same level as household spending per capita in Kazakhstan $(\$ 5,091.1)$, the best neighbor, household spending in Uzbekistan would be $\$ 167.9$ billion, which is 5.3 times the actual level. With per capita household expenditures at the same level as per capita household expenditures in Asia (\$3,445.1), household expenditures in Uzbekistan would be \$ 113.6 billion, which is 3.6 times higher than the actual level. With per capita household expenditures at the same level as per capita household expenditures in Central Asia (\$ 1,973.5), household expenditures in Uzbekistan would be $\$ 65.1$ billion, which is 2.1 times higher than the actual level.

\section{CONCLUSION}

The results of economic reform at the regional level revealed the fadedness of economic transformations without taking into account the social factors of regional development and prove the need to strengthen the social orientation of the economy. The paper proposes a system of statistical indicators of the development of households, based on the principles of a systematic approach. The proposed system of indicators expands the existing approach, which did not reflect such aspects of households as production and sale of products, employment of household members and socioeconomic efficiency of activities, and other important indicators. In the context of block indicators, the author proposes a system of statistical indicators of the functioning of households, which makes it possible to detect the regularities and quantitative changes inherent in this complex statistical aggregate. One of the characteristic features of the functioning of households is the existence of a relative lack of one factor with a relative overabundance of others. Rural unemployment and underutilized agricultural land are typical in modern conditions. The limiting factor is the lack of funds for the development of production activities. The state policy of all-round stimulation of small forms of farming in the countryside, carried out for the implementation of a national project in the field of the agro-industrial complex, may face objective difficulties in implementation, which are associated with the existing limits of expanding the scale of production activities in households.

\section{REFERENCES}

1. Carman, K. G., Liu, J., \& White, C. (2020). Accounting for the burden and redistribution of health care costs: Who uses care and who pays for it. Health Services Research, 55(2), 224-231. https://doi.org/10.1111/1475-6773.13258

2. Kuvat, Ö., \& Ayvaz Kizilgöl, Ö. (2020). An Analysis of out of Pocket Education Expenditures 
in Turkey: Logit and Tobit Models. Ege Akademik Bakis (Ege Academic Review), 231244. https://doi.org/10.21121/eab.795986

3. Li, W., Zhang, B., Lu, J., Liu, S., Chang, Z., Peng, C., ... Chen, J. (2020). Characteristics of Household Transmission of COVID-19. Clinical Infectious Diseases, 71(8), 1943-1946. https://doi.org/10.1093/cid/ciaa450

4. Yunchao, C., Yusof, S. A., Amin, R. M., \& Arshad, M. N. M. (2020). Household debt and household spending behavior: Evidence from malaysia. Jurnal Ekonomi Malaysia, 54(1), 111120. https://doi.org/10.17576/JEM-2020-5401-8

5. Durmanov, A., Umarov, S., Rakhimova, K., Khodjimukhamedova, S., Akhmedov, A., \& Mirzayev, S. (2021). Development of the organizational and economic mechanisms of greenhouse industry in the Republic of Uzbekistan. Journal of Environmental Management and Tourism, 12(2), 331-340. https://doi.org/10.14505//jemt.v12.2(50).03

6. Nurimbetov, T., Umarov, S., Khafizova, Z., Bayjanov, S., Nazarbaev, O., Mirkurbanova, R., \& Durmanov, A. (2021). Optimization of the main arameters of the support-lump-breaking coil. Eastern-European Journal of Enterprise Technologies, 2(1-110), 27-36. https://doi.org/10.15587/1729-4061.2021.229184

7. S.Umarov. Investment and Innovative Development Ways of Water Resources. American Journal of Business, Economics and Management. 2016; 4(6): 170-174

8. Umarov S., Durmanov A., Li M., Khushvaktova K., Yakubova K., Shanasirova N. (2021). Features of the application of game theory in the tasks organizational and economic mechanisms greenhouse economy. Turkish Journal of Computer and Mathematics Education, 12 (11) pp. 3544-355013.

9. Umarov S., Yusupov E., Yakubova S., Saipova M., Mamasadikov A., Khamrayeva S., Durmanov A. (2021). The cognitive model and its implementation of the enterprise Uzmobile. Turkish Journal of Computer and Mathematics Education, 12 (11) pp. 3479348614.

10. Tkachenko, S., Berezovska, L., Protas, O., Parashchenko, L., \& Durmanov, A. (2019). Social partnership of services sector professionals in the entrepreneurship education. Journal of Entrepreneurship Education, 22(4).

11. Khaustova, Y., Durmanov, A., Dubinina, M., Yurchenko, O., \& Cherkesova, E. (2020). Quality of strategic business management in the aspect of growing the role of intellectual capital. Academy of Strategic Management Journal, 19(5), 1-7.

12. Umarov, S. R., Durmanov, A. S., Kilicheva, F. B., Murodov, S. M. O., \& Sattorov, O. B. (2019). Greenhouse vegetable market development based on the supply chain strategy in the Republic of Uzbekistan. International Journal of Supply Chain Management, 8(5), 864-874.
13. Durmanov, A., Li, M., Khafizov, O., Maksumkhanova, A., Kilicheva, F., \& Jahongir, R. (2019). Simulation modeling, analysis and performance assessment. In International Conference on Information Science and Communications Technologies: Applications, Trends and Opportunities, ICISCT 2019. Institute of Electrical and Electronics Engineers Inc. https://doi.org/10.1109/ICISCT47635.2019.9011 977

14. Atakhanova, N. E., Almuradova, D. M., Khakimov, G. A., Usmonova, S. T., \& Durmanov, A. S. (2020). Values of a mathematical model for predicting the survival of patients with triple negative breast cancer depending on androgen receptors. International Journal of Pharmaceutical Research, 12(3), 695-704. https://doi.org/10.31838/ijpr/2020.12.03.104

15. Durmanov, A. S., Tillaev, A. X., Ismayilova, S. S., Djamalova, X. S., \& Murodov, S. M. ogli. (2019). Economic-mathematical modeling of optimal level costs in the greenhouse vegetables in Uzbekistan. Espacios, 40(10). 